\title{
A STUDY OF HUMAN CLONING IN IRAN'S LAW AND IN JURISPRUDENCE
}

\author{
Adeleh Keshmiri ${ }^{1}$ \\ Hamid Masjed Saraei ${ }^{2}$ \\ Davood Dadashnezhad ${ }^{3}$
}

\begin{abstract}
Human cloning is a new phenomenon that is still in the early amazing stage. In biology, cloning means "proliferation of a living creature without sexual intercourse" and is currently referred to embryonic implantation in the womb which is originally produced in the laboratory. In other words, cloning is the creation of a genetically identical copy of a human or animal that, by replacing the core of the referred person's cell and multiplying it, results in the production of a person exactly identical (or a copy) of the first person. The process is that researchers first replace nuclei of an ovum with DNA of other cells, then protect them in the laboratory to proliferate and change to embryos. If the embryo is implanted in the womb and a human being is born,
\end{abstract}

human reproduction has done. I view of Islamic jurists; human cloning is forbidden for many reasons. The present paper tries to study the cloning issue, its negative and positive consequences, and the reactions that have been shown in the world of Christianity and the West and Islamic world.

Keywords: Reproductive cloning, therapeutic cloning, Islamic world, ethical or moral issues.

\section{Introduction}

Many say that we are in the halfway of a biotechnological revolution. There have been many significant new technologies over the past twenty years that can produce new drugs for treating disease, alter genetic

\footnotetext{
${ }^{1} \mathrm{PhD}$ student, Department of Islamic jurisprudence, Damghan branch, Islamic Azad University, Damghan, Iran. Email: dadashnejaddavood@yahoo.com.

${ }^{2}$ Associate Professor, Department of Islamic jurisprudence, Damghan branch, Islamic Azad University, Damghan, Iran. Email: dadashnejaddavood@yahoo.com.

${ }^{3}$ Assistant Professor, Department of Islamic jurisprudence, Damghan branch, Islamic Azad University, Damghan, Iran. Email: dadashnejaddavood@yahoo.com.
} 
variations in plants and animals and produce bacteria to help for cleaning toxic and dangerous environmental pollution. Living creatures have never been so valuable to use during the history that can be bought and sold. At the beginning of the $21^{\text {st }}$ century, human beings have achieved the ability of mammals' cloning and human cloning, and for the first time has succeeded to produce and create his identical twins. Today, modified human being era is genetically behind us, and every day we find new genetic developments such as the production of creatures in the laboratory of producing artificial chromosomes, and the choice of gender in modern way.

Today, human cloning is one of the most controversial issues that is not only raised in the world of science but also among all of the society member. By the genetic engineering and cloning, the human domination on the nature has entered a new stage. This knowledge differs from all human finds, and there can be very dangerous consequences for humanity by a slightest negligence in its complete knowledge and application.

Reflections and reactions to cloning's future has been strengthen when the Scottish scientists Dr. Ian
Wilmut, in February 1997, declared that he has produced the first cloned mammal successfully. The cloned sheep called "Dolly" later become known as the cloning phenomenon around the world. Thereafter, many attempts were made to clone other creatures, but none of them had surprised the world as much as the one was published in November 1001. A group of American scientists claimed that they have cloned the first human embryo, although it was reported that the embryo had died in the six-cell phase. In achieving this technology, there have been many discussions on this issue with agreed and disagreed groups.

There are many questions on this issue: Why do no pay much attention to the moral and legal aspects of this important issue? Or why are the rules and regulations inadequate or have fundamental shortage in answering many related questions? Therefore, it is necessary that relevant scholars answer the raised questions by jurisprudential, legal and ethical study about cloning, and the way to chaos and violation be closed by established an appropriate law.

\section{Statement of the Problem}

\section{A-Cloning typology}


Human cloning is an unsexual human production that is almost completely identical to another human in terms of genetic- structure and protein synthesis program. Such a person is born of a rental womb and doesn't have a biological father. Today, human cloning is divided into two categories (Saremi, 2006).

\section{1-Reproduction and the Related} Approaches

Cloning for the production of children: In this case, the primary goal is to begin the process of pregnancy and the ultimate goal is the birth of child who is a genetic copy of another person. A person who lived in the past time or lives now. As stated, the purpose is to produce (or create) a human being based on a previously defined genetic combination. Proponents have various reasons for defending cloning and allow cloning in the following circumstances:

-Couples who do not have a child, whether they have already a baby or not. -A family who missed (or lost) its child because of an accident. Reproduction cloning allows parents to have twins of the missing child.
- Mothers who have lost their womb (or uterus) for medical reasons can use cloning for childbirth.

- Families whose children have inherited illness and are going to have healthy children.

\section{2- Therapeutic Research and the Related Approach}

Cloning for medical research: In this case, the primary aim is to obtain stem cells from the embryo, and the ultimate goal is to develop medical researchers in order to recognize the mechanism of congenital anomalies, to invent new treatments for disease etc.

The case for cloning is more complicated. By this technology, some fields (or tissue) can be achieved that adapted immunologically to the receptor body, and it is also applied in definitive treatment of such disease as Huntington, Parkinson, Multiple Sclerosis, heart attack and so on.

Millions of patients around the world will benefit from the results of such research, but on the other hand, this research requires the creation and then destruction of the growing embryo. Is it possible, for humanitarian purpose, to create a human embryo? It should be 
remembered that such embryo has been the starting point of the life of all human beings. We cannot cut the life cycle of this cell- set that is at the beginning of life, for medical research. However, assessment of advantages and disadvantages of this technology is so complex and hard, because on the one hand, it is promising for a huge potential benefit to humanity and, on the other hand, it will raise various ethical doubts and concerns in the society. What adds to the complexity of this issue is that, first, we cannot be sure that scientists can achieve what they claim. Second, there may be other alternative ways that can cause to these benefits without the mentioned ethical problems. Such alternatives have already been raised with suggestions such as the use of stemcells of adults.

Major concerns about the legalization of cloning therapy are based on two factors:

The first is that destruction of the original embryo cell, which has done to abuse to a new life, is the starting point for human life. Second, it is feared that if only the reproductive cloning is prohibited and reproductive cloning as allowed- since the initial stage of the two techniques are similar- this freedom is abused and embryos grow for human cloning. This concern is so severe that the United States' government strongly criticized the allowance for cloning therapy to the United Nations, and considered it as a way to reproductive cloning, because research institutes that have cloned human embryos can use it in any form, including the transfer of the embryo to a rental uterus and turn it to a human baby.

In contrast, despite followers of the cloning therapy make value and respect to the new life of the human embryos, they believe that the human dignity and legal status of a mature human will never be equal to that of a six-day old embryo; and thereafter the ethical problems caused by the destruction of this embryo is far lighter than what opponents claim. These are people who believe to "an intermediate value" for human embryos, and believe that the use of human embryos that are in the first stage of evolution is permissible if it is done within the framework of well-documented laws. Others also believe that embryo is a collection of cells and this collection has no value more than other cells in the body.

Therefore, conducting ancillary cell researches and cloning therapy is as 
well as other cellular and biological molecular researches free from any moral problems. On the other hand, it should be noted that breeding the embryos is not done for destruction, but is done in order to serve human life and advancement of medical knowledge; and in order to prevent the prolonged development of the embryo and subsequent abuse, experiments will only be carried out on embryos less than 14 days old. At this stage, the process of differentiation of organs has not yet begun. Proponents support a set of rules that allow for cloning therapy within a specific framework and prevent of violation of rules and regulations by monitoring the action. They believe that benefits of cloning therapy are so high that they cannot be ignored due to moral problems (Saremi, 2006).

\section{B- Reactions or the criminalization}

\section{Process of Human Cloning}

Scientific developments have always cause new issues and phenomenon for the human community. It usually to take years for various social systems to adapt to these new human achievements. This delay, largely due to the lack of clarification of various aspects, is a new issue for decision makers and political and intellectual leaders of society. Here, we explain and discuss about the views of global and religious leaders about the phenomenon of cloning.

\section{1-Global Reactions to the Cloning}

There are some concerns about the cloning all over the world that is apparent from statements of prominent international figures, so that it causes to reaction of performers and proponents of the cloning. For example, Mr. Rayon says about the possibility of preventing him from cloning: "If it is not possible for me to clone in land, I'll do it in the ocean". (Denier, 2003)

Jacques Chirac, the president of France, had considered human cloning a criminal offense and demanded that it be banned all over the world. He condemned that this act as opposed to human dignity and in France's view, and called on all countries to accompany France and Germany with a proposal to prevent cloning.

Franz Camp Maus, the bishop of the city of Limburg, Germany, pointing out the plan for this operation, in the United States, says: "The quest for cloning can lead to the emergence of a 
new type of slavery, and when a human being becomes a tools for research, he will lose its pride and freedom and depends on the created whims and desires (Law \& Technology Newsletter, 2003).

The German authorities also immediately stated that the human embryo cloning experiment is considered a crime against the government (and as result, the community) in Germany, and resulted in up to five years' imprisonment. In the UK, a permission letter is required for human cloning, and a board is appointed by the government for this purpose, and this board refuse to issue such permission. Violators of this issue will be sentenced to 10 years in prison. The country declared therapeutic and reproductive cloning legal in 2001. In Japan, any type of research on human cloning is prohibited, otherwise the violator will be sentenced to up to 10 years' imprisonment and a fine up to 10 million yen (equivalent to $\$ 85,000$ )Chinese authorities have forced websites such as Yahoo and MSN (owned by Microsoft) to restrict the publication of stories and negative reports about human biotechnology in Chinese language, and then they have threatened to cancel their activity license in China.

In Hong Kong, human cloning is forbidden; and in Taiwan, the bill of banning it is going to be approved (Saeidi Nejad, 2002).

Singapore, Israel, and other countries have also pointed out that if the United States, due to its ethical concerns, continues to restrict its efforts in such areas, they would be interested to continue to research in stem cells and other similar fields. Of course, the United States has created a widespread set of rules in protecting human subjects in the scientific experiments that its major reason was activities of Natural Institutes of Health. National Institute of Health, in the first years of their activities established an identical review system for evaluating research proposals, but accepted the society's demand and needs to identify acceptable risks that threatened human subjects in research. With the disclosure of the scandal of the specialized hospital for the treatment of chronic illicit diseases of the Jew in 1963 or the Syphilis Scandal in 1972, the ineffectiveness of this system was proven. These events led to the creation of a new federal regulation in 1974, aimed at protecting research subjects 
during the investigation which led to establishment of a National Commission for protection of subjects in biomedical research and behavior (Saeidi Nejad, 2002).

Currently, according to the United States Federal Law, use of tax revenues for human cloning is forbidden. In August 2002, Germany and France invited Secretary General of the United Nation, Kofi Annan to announce a draft of human cloning to be implemented around the world. Altogether, 24 countries have banned the human cloning since November 2001, including Germany, France, Japan, Brazil, South Africa and the United Kingdom.

The World Health Organization (WHO), in a resolution approved on the annual global assembly of the organization, announced human cloning of unsexual reproduction unacceptable. The resolution was cloning of unsexual reproduction unacceptable. The resolution was adapted by WHO. The organization has announced that using unsexual reproduction in order to human cloning, is morally unacceptable and is opposed to human values and morals; and it called on the Secretary General of the WHO to investigate the effects of unsexual reproductive techniques of animals and plants on human health.

Also, UNESCO, by stating the issue of duplication (or copy), ask the UN to issue a declaration as soon as possible by which prevent a research company belong to "Brigit Buissler" who has claimed for human cloning. UNESCO also asked to stop all the related discussions and scientific experiments. (Technology Rights Newsletter, 2003).

In addition, international activities that are the source of formulation of conventions, declarations and international documents, have also begun in this context, and in parallel to rapid scientific developments and biological technologies, completion and arrangement of documents is underway. These activities include "Universal Declaration on the Human Genome and Human Rights", adopted in 1997 by UNESCO General Conference, "Protocol to the Convention for the Protection of Human Rights and Dignity with regard to the Application of Biology and Medicine", adopted in April 2001, the Convention on "the Human Rights and Biomedical Sciences", and Decision No.202 of the Council of Europe on the draft protocol on the human rights and 
biomedical rights on the prohibition of cloning human beings (within the framework of the European Union).

The United Nations (and specifically the Legal Committee of the General Assembly of the Organization) has recently taken steps to develop and formulate an international convention to deal with human cloning and is going to present the convention to governments. Among the activities of sixth committee was the review of the proposed proposal for the formulation of a convention on prohibition of human cloning. The mentioned title (as schedule 174) was included in the program of $56^{\text {th }}$ General Assembly on the proposal of France and Germany and examined it at its $27^{\text {th }}$ meeting on November 19, 2001. In this regard, the sixth committee approve without a vote- and presented a draft resolution entitled "International Convention against Human Reproductive Cloning" which was presented by the France representative. The General Assembly also approved it in November 21 by reviewing the report of the sixth Committee; and the General Assembly issued a resolution in 2002 by which it establishes a special committee to review the details of the mentioned convention (Denier, 2003).

\section{2-Islamic World}

Human cloning is forbidden in view of Islamic jurists because of many reasons. They believe that because of jurisprudential, moral, social, psychological and other scientific reasons, human cloning is forbidden.

They consider that human cloning is a means of undermining religious beliefs, interfering in the creation of God, the destruction of human dignity, the confusion of family life, and the breakdown of parentage and genealogy. Therefore, they know human cloning illegitimate as in the illegal birth. The Muslim's and Catholic's jurists and scholars agree on the issue. Islamic Organizations and independent figures have repeatedly emphasized on this issue. In the Islamic world, there are many deep oppositions, that we provide views of some Islamic scholars in two parts:

1-3-Sunni scholars: The Islamic Research Association of $\mathrm{Al}$-azhar University of Cairo, the highest religious authority in Sunnis, has banned the human cloning method. "Cloning is forbidden and must be countered with it 
and prevented by any means." Aljazirah television reported of this fatwa.

Yusuf al-Qarzavi, an Egyptian resident in Qatar, condemned severity the human cloning and believed that it is in contradiction of difference in the creation. In Islam- American Relations Council also stated that experts of Islamic affairs have clearly disagreed with human cloning, and the Arab Association and the Organization of the Islamic Conference recently announced their explicit disagreement with human cloning by issuing a declaration.

The Islamic Review Assembly has considered as combatants those who carry out cloning on human beings (Qarzavi, 2003). The Islamic Medical Society organized a meeting with the participation of Islamic scholars and specialized doctors in Maghreb and condemned the human cloning under a five-articles declaration (Mohajeri, 2002).

2-3- Shi'a scholars: The Islamic Shi'a is protecting the five essential principles of "religion, soul, intellect, generation and property" that has set them as its goals and objectives; it considers a problematic and corrupt, and therefore illicit and illegal any act that threatens each of these five principles which forms the basis of a healthy person and social life.

It seems that some of the presented issues on the cloning are still exists, but here is no clear understanding of the mechanism of the relationship of the new technology with many other created changes. It is therefore appropriate to have a thorough and detailed study of the issue before judgment in order to achieve a fairer and more reasonable knowledge and judgement. Some Shi'a scholars have chosen the human cloning as the starting point and claimed that all of the presented arguments against the human cloning to be prohibited are insufficient. They state that cloning was one of the last achievements of human being that opened a clear view toward the divine knowledge and it could be used of it very effectively and without fear of creating a flaw in the creation of mankind. From this point of view, Shi'a scholars have been distinguished from Sunni scholars because the scholars' reason is based on Shi'a's principles. Current Shi's authorities consider animal cloning allowed, but they have different opinions about human cloning. 
Here, it is provided some questions and answers about animal cloning:

Question: Since we are witnessing the amazing growth of the medical science... Is it permissible to clone a living animal by the proliferation of $\mathrm{V}$ clone cells? (in this case, a cell is obtained from a living animal and reproduced with the same previous characteristics by reproducing that cell through the animal DNA information) (Judiciary Research Center of Judiciary Court, Treasury of fatwas).

In response to this fatwa, the great authorities (or jurists) said:

Ayatollah Behjat: "Apparently, it does not seem a problem."

Ayatollah Khamenei: "This is not a problem in itself".

Ayatollah Sistani: "That's Ok."

Ayatollah Safi Golpaygani: "If there is no need to violate Shi'a, it is not a problem."

Ayatollah Makarem Shirazi: "There is no problem for animals."

Ayatollah Noori Hamedani: "It is permissible for no-human beings."

Ayatollah Fazel Lankarani: There is no reason to respect this act primarily titles, although it seems problematic under the secondary titles."

But in the case of human cloning, it has been asked of the great authorities: "Since we witness the amazing growth of the technology of the $20^{\text {th }}$ century, the medical science has specifically developed and one of the important new achievements is genetic engineering and cloning that cause obscure and complex issues in the field of heredity:

A-If an embryo is protected and kept in a refrigerator (or fridge) for one hundred years or more, then implanted in the uterus of a woman and grow, can the born child of this cell, after growth and maturity, ask for inheritance property form his relatives and family?

B-If a virgin girl brings a child of her embryonic cell through the technology of cloning, is her pregnancy legitimate? Is the born child a copy of herself or her identical one or her daughter?

C-If a family have kept a copy of its child in the refrigerator and after death of their child, they implanted and reproduced the copy of the child in the mother's womb, 
in this case, whether the human's creation for a purpose unrelated to him is allowed or not?

D- If the cloning technology grows so much that mothers can look at the end of their child after a few years, can chose the embryo of different catalogues, the child grows annually but the intact copy has reserved, what is the law of such pregnancy?

In answers to such questions, Ayatollah Bahjat said:

A-“It isn't inheritance."

B- "That's O.K and like a childbirth." C- "That's O.K".

D- "There is no prohibition in terms of task and it should be referred to the same cases in terms of the transaction."

A group of jurists ordered and advised to respect:

Ayatollah Tabrizi: "It is not allowed." Ayatollah Makrem Shirazi: "This is not allowed and there is high immorality."

But some of them believed no prohibition as the priority reason (title): Ayatollah Fazel Lankarani: That's O.K as the priority title; but if it is corrupted, it is not allowed as the secondary one."
Ayatollah Noori Hamedani: "Realization of this act may not be possible and ii will be possible if it is based on Islamic principles."

Ayatollah Sistani: "There is no problem by itself."

\section{C- Human Cloning in Legal Terms}

The law is the best way of legislating in a society and no law, rule and plan should endanger the most fundamental principles of human spiritual life, which is the freedom of thought in research and science. Today, the laws, court decision, and judicial procedures should protect scientific, technical, industrial and art developments of a community.

Human cloning may legally cause some problems. Because in the cloning, the reproduced person is quite similar to the owner of the gene, even the fingerprints are not excluded of this similarity, fingerprints of everyone is unique and is an important factor in finding the perpetrator and criminal. By cloning, the owner of the gene can commit a crime and escape from the law, and then attribute his action to the reproduced person or vice versa. Therefore, the rights and freedom of the 
parties will be cancelled and abolished. In addition, the true criminal (culprit) will not be identified and the right of the oppressed is destroyed (Shariat Madari, 2005).

The cloned person has no father (because it is not a male sperm) nor a mother (because it is not combined with a female sperm), nor a sister, nor a brother and nor a relative, and he/she has been raised in womb (uterus) which is not her mother's, but is a substitute mother; in short, he/she is a person without a parentage (Alian Nejad, 1997).

If a virgin girl has a child of her genetic cell through cloning, is her pregnancy legal or not? Is the born child her daughter or the identical (or substitute) one? From whom the cloned person inherits? The blood money or retribution? Whose responsibility is the alimony and custody of the cloned person? These are questions have raised on this issue.

There is no problem in answering the mentioned ambiguities, because the jurists have responded to them, and finally they say that the cloned child has no rights in society. The uncertain condition of such a child is important because if human cloning decreases, such children should have rights like other human beings, unless there may raise many problems and reproducing such creatures should be prohibited. Even some respected jurists and lawyers who believe it legal (the primary order) disagree with it because of the ill-results that cause to produce such creatures (secondary order).

By the above statements, we conclude that human cloning is a new issue in medical science and jurisprudence. According to the principle fourth of the constitution, all laws should be within the framework of Islamic Standards. There is no specific and codified law in Iran and the violator (who does cloning) cannot be prosecuted by the court and it should be referred to the valid fatwa or morality. Therefore, it is necessary to prepare a comprehensive bill for cloning, and also a Commit of Rights and the Living Morality be established.

\section{Conclusion}

The issue of cloning is a new phenomenon in the medical science. The human cloning is done without sexual relationship; and human cloning is one of the issues that has raised reactions around the world, and is not limited to 
Islamic countries. Nevertheless, human practical sciences, both in terms of subject matter and its scope, introduce human cloning a new phenomenon which will cover the geographical scope and scientific scope on this field. International organizations and countries have not agreed on the harmonization of international rules on human and nonhuman cloning; and the United Nations has not already been able to conclude a worldwide declaration or agreement between all countries that would create a requirement for countries.

International community's opposition to the phenomenon of human cloning is worldwide and inclusive, but it seems that there are little disagreement or opposition in many countries by doing some medical researchers to deal with disease such as Parkinson, Alzheimer, heart disease and cancer through laboratory embryos and research on them in order to development in medical science and genetic engineering without considering the purpose of the researches that is reproducing human cloning.

However, some countries including the Vatican, have expressed their explicit opposition to this and oppose the human cloning with any purpose. One of the arguments of this group against human cloning is that we're producing human beings by cloning that eventually destroy or eliminate them. Hence, we will move in a direction that will lead to violations of human rights, human rights and human dignity. Do we have right to do experiment with living human being? Some say that this act will serve humanity. This may be true, do you like to be born in result of cloning and be condemned to birth for testing and the scientists' testing tools? In Islam, the followers of all Sunni religion have rejected any kind of cloning and disagreed with it as the church but the Shi' a religion agrees with it because of medical and therapeutic purposes as well as doing it on animals.

\section{References}

Ismail Abadi, Alireza. (2008). Legal ethical reflections on human Cloning. Iranian Journal of Ethics and Medical History. Pages 48-37.

Khorrami, Javad (2003). Human Cloning, Consequences and Reactions. Moballeghan Magazine No. 51, pp. 73161.

Denier, Moosa. (2003). Human Cloning from the point of view of Islamic 


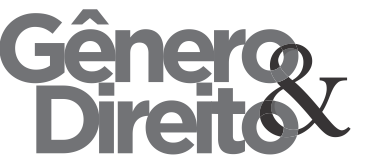

Periódico do Núcleo de Estudos e Pesquisas sobre Gênero e Direito

Centro de Ciências Jurídicas - Universidade Federal da Paraíba V. 8 - $\mathrm{N}^{\circ} 02$ - Ano 2019 - Special Edition ISSN | 2179-7137 | http://periodicos.ufpb.br/ojs2/index.php/ged/index jurisprudence. Journal of Scholars. No. 4, p. 150.

Cloning. Tehran: Sina Cultural Law Institute, First Printing, Pages 20-40.

Saeedi Nejad, Hamid Reza. (2002). Genetics and International Relations Theories: A Cashback on the Theory of the End of History. Foreign Policy Magazine. No. 61, pp. 235-246.

Cloning and Positioning of Religion and Society. (2003). Technology Law Newsletter. No. 6, pp. 66-58.

Shariat Madari, Hamid Reza. (2009). Human Cloning. Quarterly Journal of the University. No. 10, p. 122.

Saremi, Abotaleb. Yusufyan, Shervin. (2006). Cloning: Friend or Foe. Forensic Magazine. Volume 12, Issue 1, p. 50.

Aliyanejadi, Abolqasem (2000). Cloning. Quarterly journal of research and field. No. 6, p. 23.

Qarzavi, Yousef. (2003). Cloning. Translation by Nour al-din Saidiani. Journal of Dean Researchers. No. 3, p. 23.

Mohaghegh Damad, Seyyed Mostafa. (2005). Human Cloning from the point of view of Jurisprudence and Ethics. Cairo International Medical Ethics Conference. P. 34

Mohammadi Ali (2010). Cloning from the Perspective of Scientific, Moral,
Legal and Jurisprudential

Considerations. Tehran: Publishing

Ma'arf, Second Edition. P. 45

Mohajeri, Abdul Rasul. (2002). A Report on Cloning. Office of Women Studies.

Pages 2-1 